\title{
Introduction: Diversity in Nordic Children's and Young Adult Literature
}

\section{Guest editors: Lydia Kokkola and Sara Van den Bossche}

This Barnboken theme examines representations of diversity in children's literature and film from the Nordic countries. It explores diversification in terms of culture and ethnicity mainly, and also addresses questions of sexual and gender identity. The eight contributors are also diverse with respect to many of the aspects of selfhood usually considered within diversity studies: race, immigrant status, class background, (dis)ability, sexual orientation, and in terms of whether they can be considered "insiders" or "outsiders" in relation to the Nordic region. Inevitably, full-coverage of diversity has not been possible in either the analyses or in terms of the contributors' backgrounds, of which we consider cognitive impairment the most problematic. People with severe learning difficulties or acquired cognitive impairment are not able to present themselves in academic discourse, which contributes to their further othering. In our request to edit a Barnboken theme on these topics, we wanted to highlight the way in which the power valences at play (the interaction of power and affect) in the Nordic region might differ from those in other parts of the world, especially the Anglophone world.

The use of English as the language of academia is an act of power that many native speakers of the language overlook. Articles on literature produced in the so-called "small" languages - including all the national languages of the Nordic region, albeit not all the languages spoken by the inhabitants of the Nordic countries - are frequently returned with requests that the authors make references or comparisons to supposedly similar materials or events in the Anglophone world. Sometimes such comparisons have value. We have included two articles in this theme that make such direct contrasts: Lance Weldy compares British films with queer characters with a Swedish-Norwegian film based on a Norwegian novel, and Michelle

(C2020 L. Kokkola, S. Van Den Bossche. This is an Open Access article distributed under the terms of the Creative Commons Attribution-Noncommercial 3.0 Unported License (http:// creativecommons.org/licenses/by-nc/3.0/), permitting all non-commercial use, distribution, and reproduction in any medium, provided the original work is properly cited.

Citation: Barnboken - tidskrift för barnlitteraturforskning/Journal of Children's Literature Research, Vol. 42, 2019

http://dx.doi.org/10.14811/clr.v43.525 
H. Martin and Nadia Mansour present a dialogue on diversity, especially racial diversity, in the United States and Denmark. We fully acknowledge that the Nordic countries have much to learn from the struggles and successes of minorities within the Anglophone context, not least the theoretical frameworks and terminological debates that have provided the solid base for such work. However, as Rita Felski and Susan Stanford Friedman point out, comparison "is never neutral; it develops within a history of hierarchical relations" (1). The consequence of relying on comparison, they continue, is that it "distorts the uniqueness of the objects being compared, reduces them to variants of a common standard, and relies on a downgrading of certain cultures in relation to others" (1). Our focus in this theme will be on highlighting the specificities of the Nordic context, and associated approaches that might also provide useful alternatives for other parts of the world.

Before addressing those issues, however, we wish to acknowledge our own positionalities since they, too, encourage us to think comparatively. We are very aware that our relationships to the Nordic region, its languages and its literatures affect the way we see these matters. Although Lydia is a Finnish national, neither of us was born in a Nordic country: we are both outsiders who are frequently reminded of this fact, sometimes aggressively. We both grew up in European countries that had colonies in other continents, and both live and work as speakers of a minority language or non-standard variety in officially multilingual countries or regions. We are White, cisgender, and, usually, no one recognises our status as (ethnic, sexual, linguistic) "outsiders" in the Nordic countries until we speak or speak up. Between us, we understand the majority of the official languages of the Nordic countries, we have both lived in one or more of the Nordic countries, and have devoted our professional lives to the region and its literatures for youth. Our outsiderhood equips us to recognise certain aspects of diversity in the Nordic countries for instance, the racist treatment experienced by immigrants, as well as classism and colonial beliefs - precisely because we have a point of contrast in our own backgrounds. Exceptionalist thinking - the belief that one's homeland is, in some way, morally superior to other nations - exists in all countries (Hübinette; Hvenegård-Lassen and Maurer), but it is perhaps easier for those of us who are outsiders, and those who have been educated to look, to see how it is manifested in cultural production including children's literature.

To start our explication of specificities of the Nordic context, we start by drawing a contrast between our line of reasoning and the 
thinking of one of our favourite Anglophone characters: Ginger, the feminist activist chicken of the claymation film, Chicken Run (2000). In an attempt to rouse her coop sisters to join the revolution, Ginger declares, "We either die free chickens, or we die trying!" In response, the "stupid" chicken, Babs, asks the pertinent question, "Are those the only choices?" Babs fails - or, refuses? - to accept Ginger's binary thinking. Jack Halberstam (27-32) picks up on the potential of Babs' "stupidity," of humour, of silliness, and most of all of failure as a creative alternative to binary thinking. Halberstam's repositioning of failure as a form of norm critique uses numerous examples from children's films, suggesting that the silliness permitted in such materials provides greater scope for questioning norms. In short, Halberstam suggests that works intended for children might have greater potential to challenge binary thinking. It is an excellent study, but it is ultimately dependent on maintaining the success-failure binarism. As we endeavour to explicate the specificities of "the Nordic context," we too find ourselves drawn into the allure of binary thinking as we contrast it with "the Anglophone world." How, then, can we reveal specificity without distorting the uniqueness of the context? In our own article for the theme, we endeavour to answer this question by explicating the physiological origins of the human desire for comparison, and how that relates to the issue of difference at the heart of diversity.

\section{Diversity and Intersectionality in Media for Youth}

"Diversity" is the latest in a series of terms that have drawn attention to the privileging of one group as "normal" and everyone else as "other." With respect to race, earlier terms include "multicultural" and "multi-ethnic," terms that became problematic, in part, because they became associated with heavy-handed didacticism and the rather simplistic responses that assumed that simply increasing the numbers of dark-skinned characters in what Nancy Larrick, back in 1965, described as "the all-white world of children's books" would suffice. Moreover, "multicultural" is a term that has become associated with the idea of teaching White folks about Black folks, thereby heaping even more work on the already heavily burdened shoulders of writers of colour. Indeed, part of the problem with the terms has been the way they uphold Blackness/Whiteness as though the distinction were real, thereby reinforcing the hierarchical relationship caused by comparison, and occluding other issues. 
One of the issues that becomes opaque is that skin colour is used as a shortcut for describing the complexity of race. In her definition of race for Keywords in African American Studies (2018), Tricia Keaton observes that "[c]olor is not race, but it serves often as its surrogate" (165). Keaton needs to point this out precisely because the human mind easily segues between the two, and she also notes that such shorthand references can have value. In our own article for this theme, we endeavour to explain this reliance on visual information using a cognitive approach. Here, we note that the emphasis on race as a skin colour fits so poorly with the Nordic context that applications of American theorisations can allow exceptionalist thinking to flourish. If race is reduced to something one can see, then the national minorities become invisible along with the systemic racism the National Minorities Acts were designed to address.

Our intention is not to undermine much of the excellent work that has taken place under the umbrella of multiculturalism. We acknowledge that there will always be a need to update our terminology both to address new conditions and concerns, and to refresh our awareness of continuing problems. The questions posed by those interested in diversity range from asking "Who is or is not represented?" and "Who is misrepresented?" to questions about the power structures underlying such (mis)representations and evaluations of the social impact the answers to these questions will have on future societies. Those working in the sister field of inclusion endeavour to bring about changes that enable more diverse peoples to participate in the context under investigation.

One of the main challenges in work centered on notions of diversity, inclusion, and equity relates to the concept of "markedness," which we discuss further in our overview to the field. In order to make lack of representation and misrepresentation evident, differences between those who have power and those who do not need to be highlighted as "different." Unfortunately, this often results in "marking" those who have less power (as in "woman police officer") whilst leaving the other category (male in this example) "unmarked" (see e.g. Smith 35-36). Black characters' skin, hair, and eyes are often marked through description, whilst Whiteness remains unmarked and characters are described through actions or behaviours that provide more individuation. When repeated, the unmarked category (Whiteness) comes to be understood as being "normal" whilst the marked category is "different." Ebony Elizabeth Thomas's work on what she terms "the dark fantastic" shows how this marking of darkness renders it uncanny in both the sense of "haunting" and "fright- 
ening." Other unmarked, naturalised categories are male, physically and mentally able-bodied, slender, heterosexual, middle-class, and educated (see e.g. Ahmed 46). When considered separately, the majority of any given population may fall within the unmarked category (for example heterosexual), but when all categories are taken into account - as they are in intersectional analyses - very few individuals remain unmarked. Those who are not marked are privileged in ways they may not recognize themselves.

"Diversity" emerged in academic, primarily educational, discourse in the late 1980s, around the same time that "intersectionality" came into more overtly political discourse. Intersectionality highlights the way various aspects of an individual's selfhood come into play when determining the power valences in a specific situation (Crenshaw "Demarginalizing," "Urgency"; Cho et al.). Placing the terms "diversity" and "intersectionality" in conversation is fruitful. Both terms appear consciously diffuse, allowing users to highlight how aspects of selfhood - such as race, gender, health, age, size, sexual orientation, and other facets of a person's being - affect power relations in any given situation. Power is enacted both formally through laws and policies, but also through more individualised ways of being in the world. Intersectional analyses reveal how power is contextually dependent: a person who has considerable power in one situation may be wholly lacking power in another (Cho et al.). Thus, examinations of diversity and intersectionality are closely wedded to the geo-political context in which the person lives (or is depicted as living in the context of literature). As such, scholars of diversity and inclusion, much like postcolonial scholars, engage in overtly political research, much of which is intended to bring about social change (see e.g. Botelho and Kabakow Rudman 9; Dresang 19).

In addition to highlighting the situated nature of power, intersectional analyses of diversity have drawn attention to facets of selfhood that were largely overlooked in earlier scholarship. There is a considerable body of work examining matters such as race, gender, and class in relation to literature, some of which predate the presence of Literary Studies as a subject within academia (for example the writings of Frederick Douglass). Intersectional analyses not only examine the interplay between these aspects of selfhood, they also resonate with what Brian Turner has dubbed the "somatic" society, that is, "a society within which our major political and moral problems are expressed through the conduit of the human body" (6). The renewed interest in the body is evident in discussions concerning matters such as mental and physical (dis)ability, and especially noting 
how such factors interplay with race, class, and gender. This has led to the emergence of new fields, such as fat studies which acknowledges the prejudices faced by fat people. Like queer theorists and activists, those interested in fatness reclaim a term associated with abuse. Fatness has only recently been explored in relation to Nordic children's literature, with conference presentations from, among others, Åsa Warnqvist, Mia Österlund, and Maria Jönsson.

When done badly, attempts to ensure that diversity is evident to readers from all backgrounds result in works that appear to exacerbate the problems rather than solve them. For instance, Judy Blume's well-intentioned but disastrous novel, Iggie's House from 1970, described the arrival of the Garbers, the first Black family in a hitherto White residential area, from the perspective of Winnie who is White. The novel problematises race, making it an "issue" that needs to be "solved." For instance, Winnie's first question when she meets them is to ask whether they come from Africa, to which the middle child, Herbie, responds "[s] he probably thinks everybody with a black skin comes from Africa" (Blume 25). Winnie pretends she did not think this and extracts the information that the family has moved from Detroit, to which she promptly responds with a question about their involvement in the (race) riots. It continues with Winnie attempting to play the "White savior" (see e.g. Davis) by creating a questionnaire about the residents' "feelings about colored people" (Blume 71), which does at least lead her to recognise how little she understands.

Sadly, Blume's novel has parallels in Nordic fiction where Whiteness is perhaps even more normalised and unmarked than in American fiction. Jaana Pesonen's studies of recent Finnish books for children, including the very popular Tatu and Patu series by Aino Havukainen and Sami Toivonen, show how racist imagery is cloaked under ostensibly good intentions ("Xing, Sikuriina"; "Anti-Racist Strategies"). One of her studies includes examples from Anne-Mau Lehikoinen's two books about Sikuriina, a White Finnish girl whose four-year-old brother, Eric, was adopted from Tanzania (Pesonen, "Xing, Sikuriina"). As with Iggie's House, the novel's overtly anti-racist intention is marred by the heavy-handed problematisation of racial difference.

The paucity of diverse literature has an impact on young people. Empirical research by Juli-Anna Aerila in Finland and Eva Fjällström in Sweden using the technique of story completion showed that racist assumptions are widespread among children living in the predominantly White areas in which the studies were conducted. In both studies, pupils were given an extract from a work of literature (a nov- 
el in Aerila's study, the first half of a short story in Fjällström's) containing characters who were Black, and they were asked to write the ending. The pupils' endings frequently involved violence, although nothing in the extract suggested such an outcome, and nor did the original endings of the stories that the pupils read after writing their own versions. As part of this theme, Pesonen analyses a wordless picturebook depicting a young girl's flight from war, which involves a journey across the sea with her family to arrive in a place where she can build a snowman. Her pedagogical conclusion highlights the need for critical literacies and how imperfect material might foster critical literacy skills, provided awareness of the need for such skills is developed.

The difficulties of presenting diversity in text-only fiction do not fall equally on all aspects of diversity. Gender and class, for example, are more easily expressed: gender is typically marked by pronouns and class through the descriptions of the characters' homes and lifestyle. Finnish has only one third-person pronoun, "hän," to refer to both "he" and "she," but, because first names are gender-specific, binary gender is still marked. Class is, perhaps, a more interesting aspect of diversity in literature from the Nordic countries since the unfounded belief that class does not exist is still commonly asserted in everyday contexts. This oddity has its historical roots in the sudden, post-war growth from being relatively (by European standards) poor, agricultural societies to societies with some of the highest general living standards in the world. The strong presence of the social welfare system, free access to education, and well-developed state healthcare have been key components in this transformation. And, although the disparity between rich and poor is increasing rapidly, the absolute differences at the current moment are considerably less than in many other areas of the world. When class is observed, it tends to be tagged onto a more general discussion of intersectionality rather than being investigated in its own right (e.g. Alkestrand). We regard this as an area in urgent need of attention.

As is already clear, this Barnboken theme does not address all aspects of diversity, and we doubt that any collection of articles could. It is intended to open up debate of diversity in Nordic literature for youth, to consider how we got here and where research is most needed. We need diverse books in the Nordic countries, but we might have regionally specific needs that differ from those promoted by the \#WeNeedDiverseBooks movement. The discussion needs to start. 


\section{Existing Research on Diversity in Nordic Literature and Film for Children and Youth}

Clearly, there is a need to examine diversity in the Nordic countries from many perspectives, including the stories we tell our children about life in the region. This Barnboken theme on diversity endeavours to draw attention to on-going work, even as it highlights the large gaps in the field. In this section, we endeavour to situate the six articles within this theme in the context of previous Nordic research on similar topics.

One of the most important collections to date is Maria Andersson and Elina Druker's edited volume, Mångkulturell barn- och ungdomslitteratur: Analyser (Multicultural Children's and Young Adult Literature: Analyses) published in 2017. In their Introduction, they note that the term "multicultural" is used in numerous different ways ranging from simply counting the frequency with which nonmajority characters occur to identifying the social function of literature, and highlight the limitations of us-them thinking, whether that relates to race, class, gender, or other facets of selfhood. As far as we are aware, theirs was the first study to address maingkultur ("multiculture") and diversity on such a scale. The contributions deal with a wide range of genres - novels, diaries, picturebooks, comic books, and more - and geographically range from the Northernmost corners of Europe to Africa, India, and Australia. In terms of authorship, too, the anthology advocates diversification, in a certain sense, as the editors solicited academics from different fields within and outside children's literature studies.

Andersson and Druker structured the anthology around three themes: svenskheter (ways of being Swedish), kulturmöten (intercultural meetings), and främlingskap och främmandegöring (strangerhood and alienation). The contributions are organised around a number of theoretical approaches and concepts, which recur throughout the threeparts. Theseincludeothering, us-them thinking, exoticism, intersectionality, Orientalism, alienation, and outsiderhood. Together, these concepts create a red thread ${ }^{1}$ throughout the collection and thus a sense of cohesion. The section that addresses meetings between cultures helpfully and rightfully highlights the presence of a colonial mindset in many of these encounters. Although not all of the contributions are equally theoretically solid and some are decidedly descriptive, all do important work in terms of topicalising mångkultur, normativity, and diversity. In our view, the main strengths of the anthology are, firstly, that it addresses svenskheter - ways of being 
Swedish - that have long been neglected and are in dire need of attention in relation to those in the periphery, such as Sámi and Roma minorities. Importantly, these contributions foreground the colonial mechanisms that affect the social stature and daily lives of these minority groups to this very day. In doing so, the collection as a whole works to counteract the "colonial amnesia" Kirsten HvenegårdLassen and Serena Maurer identify in Scandinavia (156). An additional strong point is that many of the chapters - if not all of them - deal with cases that are ambivalent. The stories these contributions tell are not about texts or artefacts that are to be read as either/or, black/ white, yes/no, us/them, but rather cases that exhibit a little bit of many things, which question normativity, and challenge standards. The consistent effort to call into question what is perceived as the norm is perhaps the most significant achievement of this anthology.

In the field of diversity studies in a Finnish context, Pesonen, one of the contributors to this theme, has produced a number of relevant studies. For instance, in her chapter in the collection Looking Out and Looking In: National Identity in Picturebooks of the New Millennium (2013), edited by Åse Marie Ommundsen, Pesonen scrutinises the representation of nationality in contemporary Finnish picturebooks. Her study lays bare an evolving, expanding notion of what it means to be Finnish, namely a "diversified Finnishness" (Pesonen, "Nationality" 129). She traces an evolution from a construction of nationality heavily rooted in a binary conception of Whiteness to predominantly depicting diversity in implicit ways, that is, as normal and natural: "not seen only as connected to ethnicity, but as more complex and multidimensional" (129). Drawing on John Stephens, Pesonen argues that this approach "can function as a strategy to reduce the sense of otherness of minority groups" (126).

Also in Looking Out and Looking In, the Danish scholar Nina Christensen probes the existence of a specifically Nordic construction of childhood, as opposed to a child image that envisions children as global citizens. In the alleged particularly Scandinavian construction of the child, children are cast as independent, agentic, and competent citizens. As Christensen offers, "children are thought to be reflective, active individuals who develop and define their own identity in interaction with other people, both children and adults" (188). Drawing on Helene Brembeck, Jan Kampmann, and Barbro Johnsson (20), Christensen explains that this type of child is "autonomous and self-regulating [...] It is a reliable child, well worth listening to, as it is able to rationally express wishes, interests and feelings" (Christensen 189). She then goes on to add that, based on research by schol- 
ars outside of Scandinavia, this is by no means a specifically Nordic concept of childhood. Indeed, she - like us - suggests it is pervasive elsewhere as well.

Given the observed prevalence of the notion of the competent, agentic, and well-spoken child, and within the context of this particular Barnboken theme, we deem it fair to ask which children can avail themselves of opportunities to gain such autonomy. It is safe to assume that not all children have access to the type of existence in which they can exert their "right to and possibility to make independent choices and their right to express their own needs and beliefs ([James and] James 2008, 9)" (Christensen 188). Not all children live in an environment where they are "urged to practice constant self-explication, self-evaluation and self-reflection, the core premise being children as knowing and searching, mature and rational and equal negotiation partners to adults (Brembeck et al. 2004, 20)" (Christensen 189). This prevalent child image is indeed an outspokenly privileged one.

This competent child has come to replace the romanticised, innocent child of yore, but has not shed her forebear's characteristics. As a privileged child, the competent child is still innocent. It would therefore be meaningful to ask, with Robin Bernstein, whether or not that child is White. If we were to venture a guess, we would hazard an affirmative answer. Bernstein argues that in the aftermath of slavery, "angelic white children were contrasted with pickaninnies so grotesque as to suggest that only white children were children," which led to the "exclusion of black youth from the category of childhood" (16). Childhood, then, is a normative category, much like Whiteness, and, in tandem, the two establish a specific mode of being that is preferred and hierarchically more valuable than others. Building on Bernstein's rationale, we may safely argue that the presence of other vectors of non-majority identities, pertaining to ability, class, or gender, can work to position children as outsiders, as non-children.

There are a few texts that focus on class in Nordic, or at least Swedish, children's and young adult literature, although they are rare in number. A notable example is Magnus Nilsson's "Skildringen av arbetarklassen i Sven Wernströms Trälarna: 1900-talet" (The Depiction of the Working Class in Sven Wernström's Trälarna: The 1900s) in Andersson and Druker's Mångkulturell barn- och ungdomslitteratur. First of all, it is striking that this contribution to a collection on children's and young adult literature is written by a scholar who does not normally conduct research on children's and young adult books. The choice of author suggests that the topic is not that common or 
familiar for scholars from within the field. Nilsson makes the important point that restricting investigations of multiculturalism to ethnicity and migration is problematic, because this focus may obscure the homogenising tendencies of other vectors of collective identity, among which he highlights class as very prominent (73). Significantly, Nilsson claims that even the genre of arbetarlitteratur (working-class literature) thematises the multicultural society, as it challenges the impression of homegeneity by foregrounding contrasts between different classes (74). By stressing the heterogeneity of group identities that may come across as homogeneous, Nilsson ties in with the aforementioned intersectional approach (Crenshaw "Demarginalizing," "Urgency"; Cho et al.).

Clearly, there is still much work to be done. But it is our fervent hope that this Barnboken theme on diversity will provide another stepping stone towards addressing these inequalities in the materials we offer our children, and in how we teach them to respond to these issues both as critical readers and in the world. If this competent child is indeed White (and able to learn, educated, middle class, and privileged in other ways), then using these unearned advantages to become good allies is, if we may use an unfashionable term, a moral obligation.

\section{The Theme of Diversity in Barnboken}

We begin the theme with our own article, which is intended to provide an overview of the current state of play in relation to diversity in Nordic fiction for children and youth using cognitive approaches to suggest why the tendency to rely on binary thinking is so difficult to overcome. This is followed by an article by Michelle H. Martin and Nadia Mansour which overtly contrasts diversity studies in the American and Danish contexts. Whilst American research has gone further to document and highlight problems of representation, noting that the racial diversity of authors of and characters in children's literature does not reflect the racial diversity of the American population, Danish authors have resisted attempts to classify them as representatives of their group. Mansour's research has focused on inclusion: examining how facets of selfhood affect the ability to act in society, she examines diversity through content and style, not the author's membership to a particular group (see also Mansour's Multikulturel litteratur i danskfaget). Moreover, we see less focus on the visual in the Danish studies cited by Mansour. 
The third article, by Jaana Pesonen, examines Finnish refugee narratives with a special focus on a wordless picturebook. She begins by discussing the work in terms of its representation of the refugee experience, but, like Mansour, her underlying, albeit unstated, goal is to promote inclusion. She describes her work with teachers and classroom assistants, and the ways in which the book, despite its imperfections, can be brought into the classroom to promote critical literacy skills. Anna Karlskov Skyggebjerg also discusses refugee narratives by providing an overview of recent Danish fiction, which she contextualises in relation to the humanitarian crises witnessed in the past five years. Like Pesonen, Karlskov Skyggebjerg is concerned with questions such as the use of voice and how silence might be considered both a form of repression and a means of communication.

JoAnn Conrad, for her part, contrasts early children's literature about the Sámi with more recent works written by and for the Sámi. She quickly moves beyond observations on the obvious racism in the portrayal of the Sámi characters to examine mythical characters such as Stallo and the uldat. She shows how the portrayals of these characters in folklore, fiction by non-Sámi, and in Sámi fiction for children differ markedly, and reflects on the long-term situation for future generations.

The theme concludes with an article by Lance Weldy comparing three films from the 1990s: two British and one Swedish-Norwegian film based on a Norwegian novel. Whereas the other articles for this theme all examine race and ethnicity as elements of diversity, Weldy highlights sexual orientation and, to a lesser extent, class in his discussion of the aesthetics of the gay male protagonists. By situating the boys' coming-out stories in the socio-political contexts of the two countries, Weldy endeavours to show how sexual diversity in the Nordic countries differs from other parts of the world. We hope you enjoy the articles, but more urgently, we hope they provoke debate on different forms of diversity in Nordic children's literature.

Biographical information: Lydia Kokkola works as a Senior Lecturer of English language learning and teaching at Oulu University, Finland. Her most recent works in the field of children's literature have focused on embodiment, often using cognitive approaches to understand the physicality of the reading experience. She is currently one of the coordinators of EmLearning, a Nordic network for scholars interested in embodied cognition and its implications for education. Sara Van den Bossche is Assistant Professor of Children's Literature Studies at Tilburg University, the Netherlands. In her doctoral dissertation (Ghent University, Belgium, 2015), she scrutinised the reception and canonisation of Astrid Lindgren's works in Flanders 
and the Netherlands. Her main teaching and research topics are ethnic and cultural diversity, cognitive criticism, canonisation, adaptation, and picturebooks. Since September 2019, she has been teaching in the Erasmus Mundus International Master "Children's Literature, Media, and Cultu$r e^{\prime \prime}(C L M C)$.

\section{Works Cited}

Aerila, Juli-Anna. "Using Multicultural Literature as a Tool for Multicultural Education in Teacher Education." International Association for the Improvement of Mother Tongue Education Conference (IAIMTE, now ARLE), 2016, http://ininet.org/download/ using-multicultural-literature-as-a-tool-for-multicultural-edu. doc. Accessed 3 December 2017.

Ahmed, Sara. Strange Encounters: Embodied Others in Post-Coloniality. London/New York, Routledge, 2000.

Alkestrand, Malin. "Adolescent Killer and Politican: Age-Related Ideologies in the Dystopian Future Sweden of Mats Wahl's Blood Rain Series" HumaNetten, vol. 43, 2019, pp. 207-229.

Andersson, Maria, and Elina Druker. Mångkulturell barn- och ungdomslitteratur: Analyser [Multicultural Children's and Young Adult Literature: Analyses]. Lund, Studentlitteratur, 2017.

Bernstein, Robin. Racial Innocence: Performing American Childhood from Slavery to Civil Rights. New York/London, New York University Press, 2011.

Blume, Judy. Iggie's House. 1970. London, Pan Books Limited, 1988.

Botelho, Maria José, and Masha Kabakow Rudman. Critical Multicultural Analysis of Children's Literature: Mirrors, Windows, and Doors. London/New York, Routledge, 2009.

Brembeck, Helene, Jan Kampmann, and Barbro Johnsson, editors. Beyond the Competent Child: Exploring Contemporary Childhoods in the Nordic Welfare Societies. Frederiksberg, Roskilde Universitetsforlag, 2004.

Cho, Sumi, Kimberlé Williams Crenshaw, and Leslie McCall. "Toward a Field of Intersectionality Studies: Theory, Applications, and Praxis." Signs, vol. 38, no. 4, 2013, pp. 785-810, doi. org/10.1086/669608. 
Christensen, Nina. "Contemporary Picturebooks in the Nordic Countries: Concepts of Literature and Childhood." Looking Out and Looking In: National Identity in Picturebooks of the New Millennium, edited by Åse Marie Ommundsen, Oslo, Novus Press, 2013, pp. 183-194.

Crenshaw, Kimberlé. “Demarginalizing the Intersection of Race and Sex: A Black Feminist Critique of Antidiscrimination Doctrine, Feminist Theory and Antiracist Politics." University of Chicago Legal Forum, vol. 1, 1989, pp. 139-167.

---. "The Urgency of Intersectionality." ted, 2016, www.ted.com/ talks/kimberle_crenshaw the urgency_of intersectionality. Accessed 28 September 2020.

Davis, Jewel. "(De)constructing Imagination: Racial Bias and Counter-Storytelling in Young Adult Speculative Fiction." Study and Scrutiny: Research on Young Adult Literature, vol. 4, no. 1, 2020, pp. 1-28, doi.org/10.15763/issn.2376-5275.2020.4.1.1-28.

Dresang, Eliza. "Opening Doors to Understanding: Developing Cultural Competence through Youth Literature." Diversity in Youth Literature: Opening Doors through Reading, edited by Jamie Campbell Naidoo and Sarah Park Dahlen, Chicago, ALA Editions, 2013, pp. 17-29.

Felski, Rita, and Susan Stanford Friedman, editors. "Introduction." Comparison: Theories, Approaches, Uses. Baltimore, JHU Press, 2013, pp. 1-14.

Fjällström, Eva. "Emeralds, Rubies and Gems of Reader Engagement." The $19^{\text {th }}$ European Conference on Literacy, Klagenfurt, Austria, 13-16 July 2015. Paper.

Halberstam, Judith/Jack. The Queer Art of Failure. Durham, Duke University Press, 2011.

Hübinette, Tobias. "'Words that Wound': Swedish Whiteness and its Inability to Accommodate Minority Experiences." Whiteness and Postcolonialism in the Nordic Region: Exceptionalism, Migrant Others and National Identities, edited by Kristín Loftsdóttir and Lars Jensen, Oxon/New York, Routledge, 2012, pp. 55-73.

Hvenegård-Lassen, Kirsten, and Serena Maurer. "Bodies and Boundaries." Whiteness and Postcolonialism in the Nordic Region: Exceptionalism, Migrant Others and National Identities, edited by Kristín Loftsdóttir and Lars Jensen, Oxon/New York, Routledge, 2012, pp. 154-182. 
James, Allison, and Adrian James. Key Concepts in Childhood Studies. London, Sage, 2008.

Keaton, Tricia. "Race." Keywords in African American Studies, edited by Erica Edwards, Roderick Ferguson and Jeffrey Ogbar, New York, New York University Press, 2018, pp. 163-167.

Larrick, Nancy. "The All-White World of Children's Books." Journal of African Children's and Youth Literature, vol. 3, 1965, pp. 1-10.

Mansour, Nadia. Multikulturel litteratur i danskfaget: Kulturer, læsemåder og litterær inklusion [Multicultural Literature in the Subject Danish: Culture, Modes of Reading, and Literary Inclusion]. Dissertation. Aarhus, Aarhus University, 2020.

Nilsson, Magnus. "Skildringen av arbetarklassen i Sven Wernströms Trälarna: 1900-talet" [The Depiction of the Working Class in Sven Wernström's Trälarna: The 1900s]. Mångkulturell barn- och ungdomslitteratur: Analyser [Multicultural Children's and Young Adult Literature: Analyses], edited by Maria Andersson and Elina Druker, Lund, Studentlitteratur, 2017, pp. 73-87.

Park, Nick, and Peter Lord, directors. Chicken Run. Aardman and Dreamworks, 2000.

Pesonen, Jaana. "Anti-Racist Strategies in Finnish Children's Literature: Physical Appearance and Language as Signifiers of National Belonging." Children's Literature in Education, vol. 44, no. 3, 2013, pp. 238-250, doi.org/10.1007/s10583-012-9186-Z.

---. “Nationality in Finnish Children's Literature: From Representations of Ethnic Difference to Representations of [sic] Culturally Diverse Society." Looking Out and Looking In: National Identity in Picturebooks of the New Millennium, edited by Åse Marie Ommundsen, Oslo, Novus Press, 2013, pp. 119-132.

---. “Xing, Sikuriina, Tatuja Patu:Monimuotoinen monikulttuurisuus 2000-luvun lastenkirjoissa" [Xing, Sikuriina, Tatu and Patu: Diverse Multiculturism in Children's Literature in the 2000s]. Kaikille lapsille: lastenkirjallisuus liikkuvassa, monikulttuurisessa maailmassa [For All Children: Children's Literature in a Changing, Multicultural World], edited by Anna Rastas, Helsinki, Suomalaisen Kirjallisuuden Seura, 2013, pp. 62-82.

Smith, Angela. "Paddington Bear: A Case Study of Immigration and Otherness." Children's Literature in Education, vol. 37, no. 1, 2006, pp. 35-50, doi.org/10.1007/s10583-005-9453-3. 
Stephens, John. Language and Ideology in Children's Fiction. London/ New York, Longman, 1992.

Thomas, Ebony Elizabeth. The Dark Fantastic: Race and the Imagination from Harry Potter to The Hunger Games. New York, New York University Press, 2019.

Turner, Bryan S. The Body and Society. $2^{\text {nd }}$ ed. Oxford, Blackwell, 1996.

Warnqvist, Åsa, Mia Österlund, and Maria Jönsson. “Body Politics and the Fat Child." IRSCL Congress 2017: Possible \& Impossible Children: Intersections of Children's Literature \& Childhood Studies, 1 August 2017, York University, Toronto. Panel.

\section{Notes}

1 For our non-Nordic readers: a "red thread" is a line of argument or narrative which holds the text together. The metaphor comes from sewing, where red threads were used to tack pieces of fabric together, but can relevantly be compared with a blood vein feeding the body of the text. 